\title{
Potential use of Fly Ash as Partial Replacement of Cement in Concrete
}

\author{
Conhyea $\mathbf{M}^{\mathbf{1}}$, Goodary $\mathbf{R}^{\mathbf{1}}$ \\ ${ }^{1}$ Université des Mascareignes \\ Avenue de la Concorde, Roches Brunes, Rose Hill, Mauritius \\ Mahen.conhyea@gml.mu; rgoodary@udm.ac.mu
}

\begin{abstract}
The aim of this research is to investigate the effect of fly ash, used as partial replacement to cement CEM I $42.5 \mathrm{~N}$, on the properties of fresh and hardened concrete. Fly ash, acquired from a local Thermal Energy Operations industry, based on the island of Mauritius is used to prepare various trial mixes namely FA5, FA10, FA15, FA20, FA25, FA30, FA40 and FA50 with partial replacement of cement by $5 \%, 10 \%, 15 \%, 20 \%, 25 \%, 30 \%, 40 \%$ and $50 \%$ of fly ash respectively. The behaviour and strength properties of the samples have been compared to an equivalent mix of plain cement concrete - FA0. At first the tests have been performed on mortar specimens to establish the optimum amount of fly ash which yields maximum compressive strength. As such, samples are prepared from 9 different mixes by substituting only cement by Fly Ash, keeping the total amount of binder constant. The cement, fly Ash, sand and water are mixed together in compliance with prevailing standards - EN 196-1. Mortar samples are cured and matured at $20^{\circ} \mathrm{C}$. Results show that $15 \%$ fly ash replacement of cement yields a maximum compressive strength of $42.5 \mathrm{MPa}$ equating to CEM II 42.5 equivalent streng th. Fly Ash with LOI $5 \%$ is then used to prepare concrete samples. Concrete of grade 25 has been selected for testing activities to comply with its high demand in Mauritius, i.e. $60 \%$ of the local market. Tests are performed on cubes for each trial mix to determine the compressive and flexural strengths respectively after 2, 7 and 28 days. Compressive and Flexural strengths are found to vary in the range of $10.3-33.1 \mathrm{MPa}$ and $0-9 \mathrm{MPa}$ respectively for the said grade 25 concrete containing $263.5 \mathrm{Kg}$ of cement and $46.5 \mathrm{Kg}$ of fly ash per $\mathrm{m}^{3}$ of concrete.
\end{abstract}

Keywords: Fly Ash, Carbon Burn Out, Mortar, LOI, Cogeneration, Compressive and Flexural Strengths.

\section{Introduction}

Energy in the form of electricity is a necessity for economic development and social progress. The necessity of providing electric power to the rapidly growing industries as well as agricultural sectors, mainly the sugar cane industry, has resulted in the establishment of 4 Coal based Thermal Power Stations in Mauritius [1,2]. In these Thermal Power Stations, the burning of coal at high temperature $\left(950^{\circ} \mathrm{C}\right)$ produces $120 \mathrm{Kt}$ of coal ash as a waste material. The huge quantity of coal ash being accumulated over the years is likely to become a serious problem for its disposal and cause severe environmental pollution leading to health hazards. To minimize all these effects, one of the alternatives is to promote large-scale utilization of Coal Ash as raw material in concrete and mortar. Though a large number of significant results $[3,4,5,6,7]$ have been reported on the use of fly ash in concrete, in Mauritius there is no literature or research available on the use of fly ash as partial replacement of cement in concrete.

The linear system, illustrating the consumption of coal and cement $[8,9,10]$ for the Mauritian economy is represented in Fig 1. 


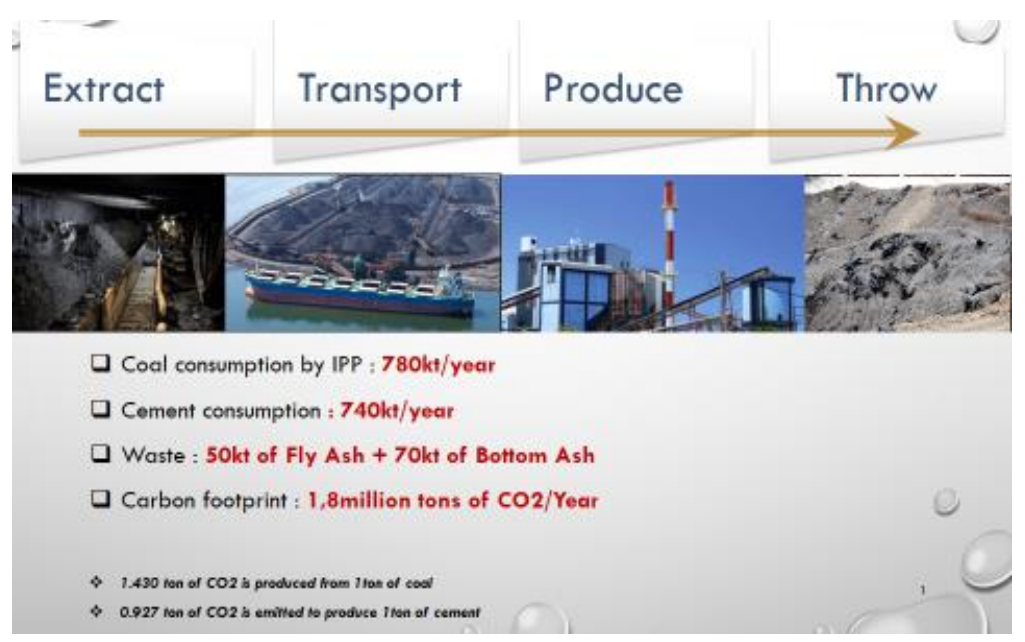

Fig. 1: Linear system of the Mauritian Economy.

The current transition objective of the government is to break the Linear System and shift towards a Circular Sustainable Economy with Concrete, incorporating Fly Ash and Cement. Presently the CEM II/A-V 42.5 is commercialised in the local market. Thus, reducing the importation of cement by 50ktons.

\section{1. Carbon Burn-Out (CBO)}

Authors have successfully carried out some researches in collaboration with the above local private power producer, regarding how to improve the Loss of Ignition (LOI) of Coal Ash, which is currently > 20\% for Fly Ash $[11,12]$ and $>30 \%$ for Bottom Ash [8]. Because of the absence of necessary facilities on the island, both BA and FA were sent to Pune, India, to burn the latter in a small CBO model, namely 'Thermax' with appropriate testing carried out on the final product. The results were found to be a satisfactory with a LOI $<5 \%$. After having complied with the local environmental regulatory exigencies, authorisation from the local authorities for the setting up of a Carbon Burn-Out unit [9] in the south of the island, was approved.

The idea behind the Carbon Burn-Out (CBO) project is to burn the extra carbon in the power plants' fly ash and bottom ash - and in the process, reduce their carbon content from 30\% to < 5\% (OTEOLB, 2013). The CBO unit re-injects the ash back into the furnace where it is further burnt to recuperate a certain amount of energy that is still contained in the waste material. The Fly Ash leaves the furnace with a lower amount of unburnt carbon as compared to before - currently < $2 \%$. Since the beginning of 2019 , this ash is added up to $20 \%$ in cement of standard CEM I 52.5 to produce a CEM II/A-V 42.5.

Figures 3-5 explicitly show the characteristics of these materials. The characterization of materials [13] was performed at LERM laboratory, France.

Microscopic studies on CEM I 52.5, Fly Ash, and Blend CEM II/A-V 42.5 (CEM I 52.5N + 20\% Fly Ash) were carried out by SEM (Scanning Electron Microscope) combined with EDX (Energy-dispersive X-ray).

The CEM I 52.5 $\mathrm{N}$ has the following constituents and particles (fig 3):

- Portland clinker grains, some of which contain a phase of oxides of magnesium

- a few grains of calcium sulfates of similar diameter

- mineral grains of Silico Alumino Sodic nature, Silico magnesium, polyphase grains composed of silicon, aluminum, magnesium and iron elements. It could be pozzolanic, possibly of natural origin. 

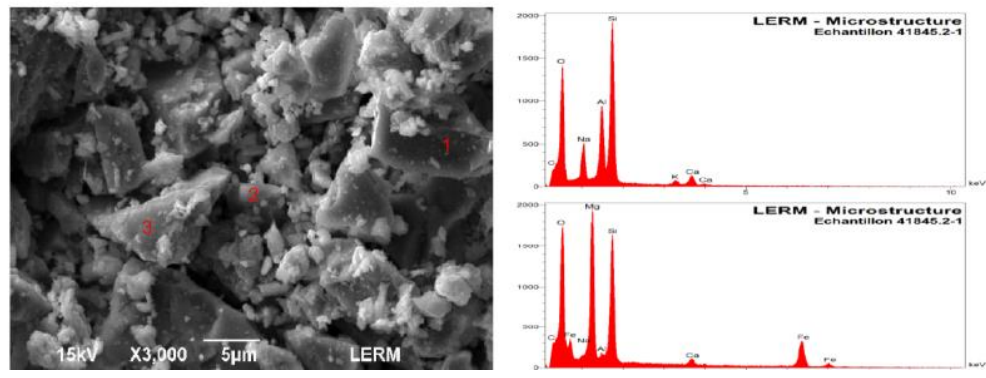

Fig. 3: General appearance of CEM I 52.5.

The Fly Ash consists of relatively fine particles (fig 4) with mean diameter between 5 and 15 microns ( maximum diameter measured is in the range of $40-50 \mu \mathrm{m}$, and the minimum diameter is $1 \mu \mathrm{m}$ ). These particles have various forms, usually rather rounded to spherical ash. The surface appears to be smooth to granular with the main composition being silico-alumino-ferrous component, including traces of magnesium, calcium, sodium, phosphorus and titanium.
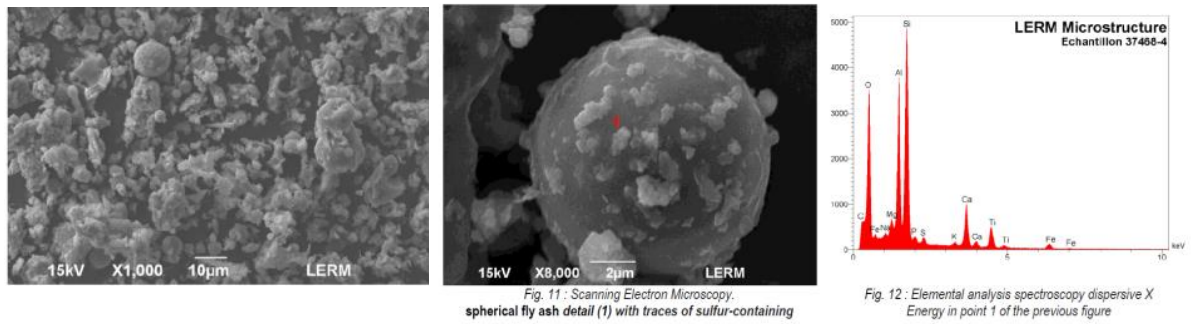

Fig. 4: General appearance of fly ash LOI $2 \%$ from CBO-OTEO LB.

The blend CEM II/A-V 42.5 has the same constituents and particles as CEM I $52.5 \mathrm{~N}$ above, that is Portland clinker grains with a phase of oxides and of magnesium, grains of calcium sulfates, particles of Silico alumino Sodic nature, Silico magnesium, polyphase grains composed of silicon, aluminium, magnesium and iron elements and additionally CEM II/A-V 42.5 contains some aluminous silico fly ash, of various shapes (compact spheres, microporous grains) as shown in Fig. 5 below.
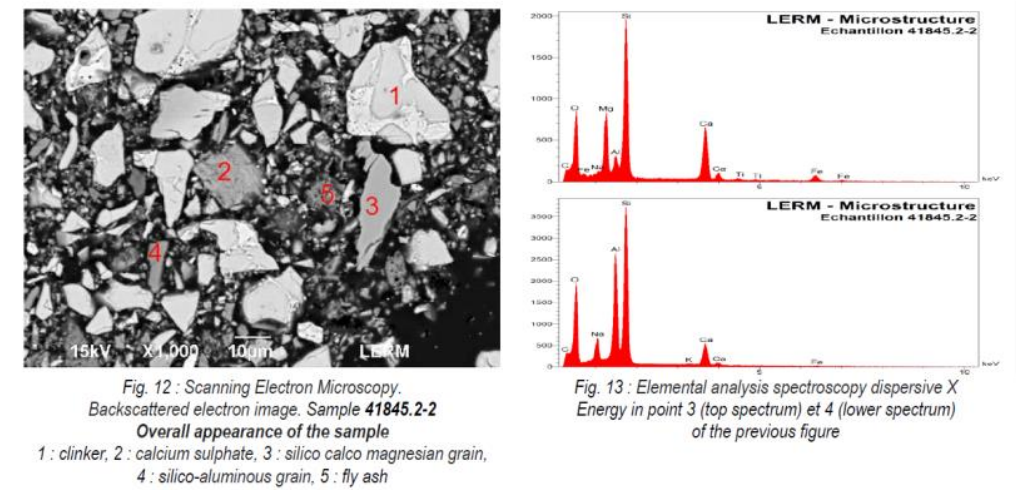

Fig. 5: General appearance of Blend cement CEM II/A-V 42.5 (CEM I $52.5+20 \%$ FA). 


\section{Experimental study}

Samples of Fly Ash were received from a local Thermal Energy Operations industry, based on the island of Mauritius. Various tests were carried out in order to determine the compressive strength of hardened concrete after partially replacing cement by FA in the concrete mixes $[14,15,16]$. The fly ash sample was added to sand/cement mortars and then in concrete with the Fly Ash as partial replacement to cement. Prism and cube samples were tested to determine the compressive strength after 2 days, 7 days and 28 days respectively.

The effect of using FA as a replacement to cement in concrete was also determined on the compressive strength of the concrete, when tested in accordance with BS EN 12390-3:2009 'Testing hardened concrete - Compressive strength of test specimens'. Trial mixes were carried out with the only variable being the percentage by mass of cement and FA in concrete.

\section{1. Mortar tests as per BS EN 197-1 (Year 2014)}

Mortar prisms $40 \mathrm{~mm}$ x $40 \mathrm{~mm}$ x $160 \mathrm{~mm}$ were prepared to determine the compressive and flexural strengths. Results are shown in Figures 6 and 7.

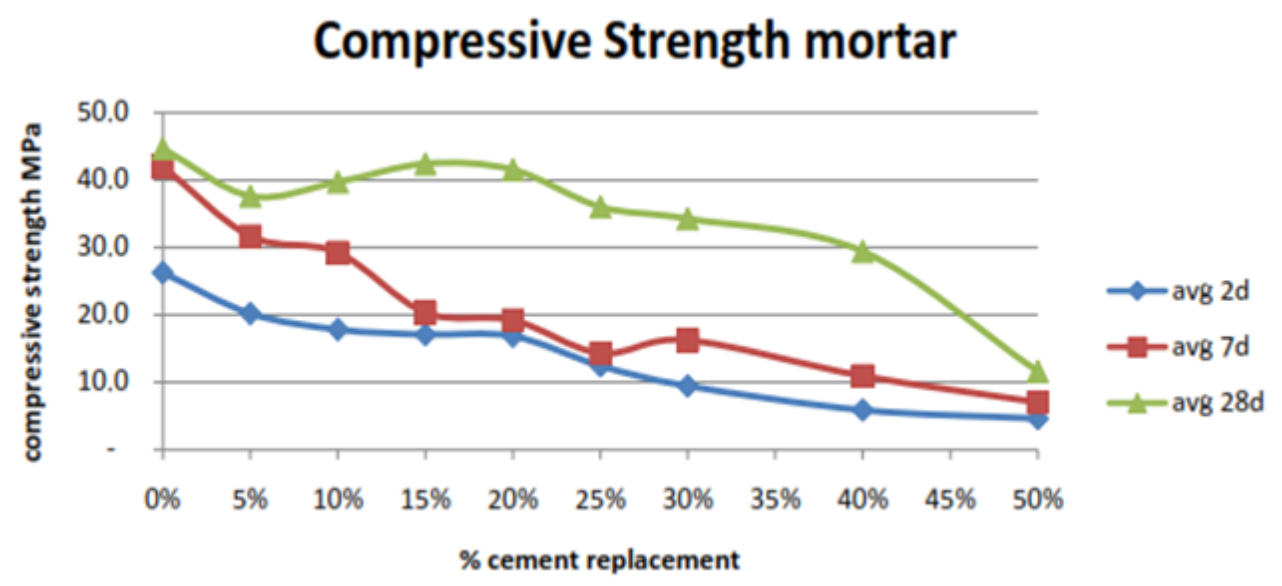

Fig. 6: Compressive strength at different curing days of mortar.

\section{Flexural Strength Mortar}

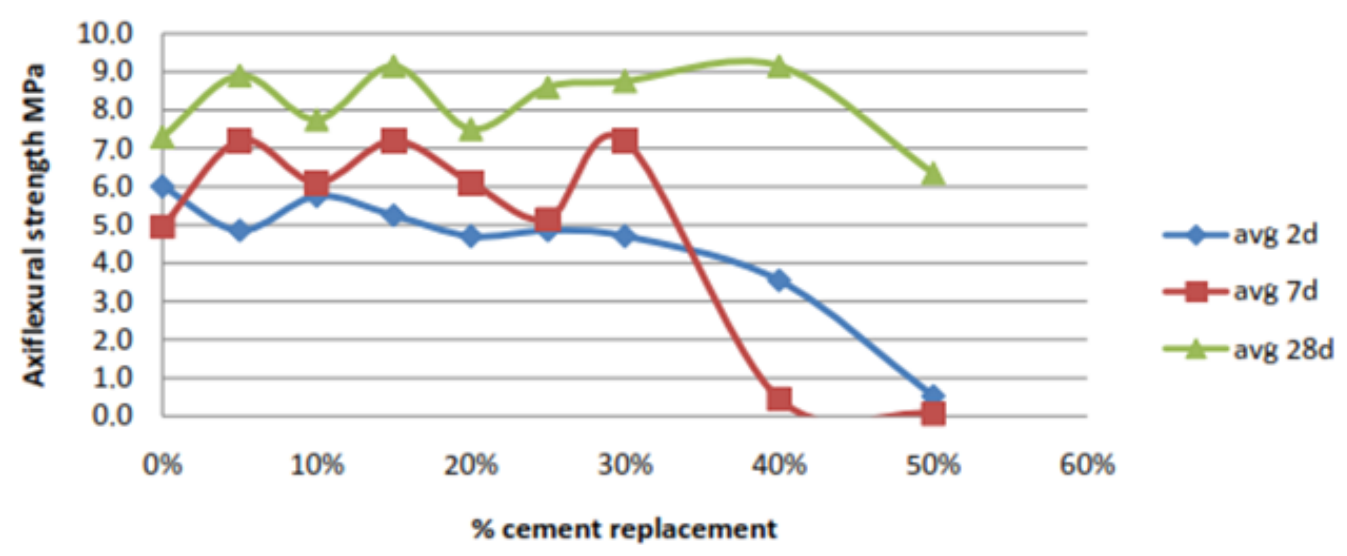

Fig. 7: Flexural Strength as a function of cement replacement. 


\section{2. Concrete mix with $15 \%$ fly ash as partial replacement of cement}

The following raw materials were used for the preparation of concrete samples:

Cement: Ordinary Portland Cement CEM I 42.5N, supplied by Kolos (Mauritius) Ltd.

Fly Ash: FA with LOI < 5\%, as received from OTEO LB, Mauritius.

Fine Aggregates \& Coarse aggregates: Natural sand conforming to BS EN 12620

Additive: A commercially available plasticizer, SikaPlast 60MU.

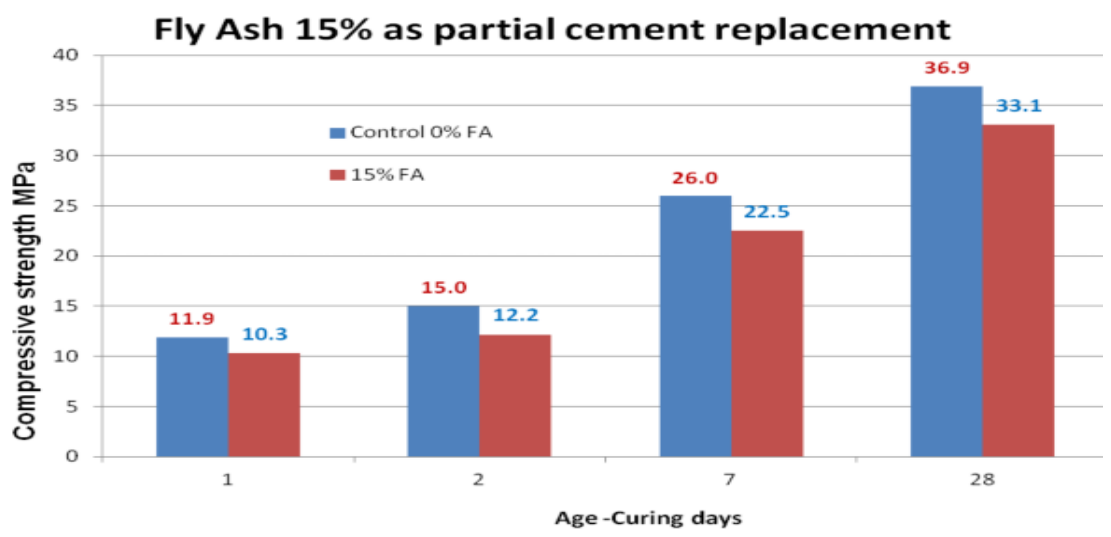

Fig. 8: Compressive strength for a grade 25 with $263.5 \mathrm{Kg}$ of cement $+46.5 \mathrm{Kg}$ of FA (LOI $<5 \%)$.

Based on results presented in fig 6 , it is noted that the compressive strength starts to drop significantly above $25 \%$ of partial replacement of cement by Fly Ash with a LOI less than 5\%. Results show that $15 \%$ fly ash replacement of cement yields a maximum compressive strength of $42.5 \mathrm{MPa}$ equating to CEM II A42.5 equivalent strength. It also reveals that there is decrease of $10 \%$ with the blend of $15 \%$ fly Ash compared to Control CEM I $42.5 \mathrm{~N}$.

\section{3. Mortar tests as per BS EN 197-1 (Year 2018)}

Based on results shown in Fig 8 above and with an aim to compensate the 10\% decrease in compressive strength, CEM I $42.5 \mathrm{~N}$ has been replaced by CEM I $52.5 \mathrm{~N}$ and Table 1 below explicitly shows the outcome.

Table 1: FA with LOI < 2\% as partial replacement in CEM I 52.5.

\begin{tabular}{|c|c|c|c|c|c|c|c|}
\hline \multirow{2}{*}{ Fly Ash (\%) } & \multirow{2}{*}{ Prism description } & \multicolumn{3}{|c|}{ Flexural Strength (MPa) } & \multicolumn{3}{|c|}{ Compressive Strength (MPa) } \\
\cline { 3 - 8 } & & $\mathbf{2 d}$ & $\mathbf{7 d}$ & $\mathbf{2 8 d}$ & $\mathbf{2 d}$ & $\mathbf{7 d}$ & $\mathbf{2 8 d}$ \\
\hline 8 & CEM II/A-V (8\% FA) & 4.8 & 6.2 & 4.4 & 25.5 & 41.5 & 54.1 \\
\hline 15 & CEM II/A-V (15\% FA) & 4.0 & 5.5 & 6.5 & 24.0 & 39.4 & 53.7 \\
\hline 20 & CEM II/A-V (20\% FA) & 4.8 & 6.7 & 8.1 & 23.3 & 37.9 & 49.5 \\
\hline 25 & CEM II/A-V (25\% FA) & 4.2 & 4.6 & 4.3 & 21.9 & 35.5 & 48.3 \\
\hline 30 & CEM II/A-V (30\% FA) & 4.1 & 5.8 & 7.2 & 18.5 & 31.1 & 47.8 \\
\hline 40 & CEM II/A-V (40\% FA) & 3.2 & 5.0 & 6.8 & 13.5 & 26.7 & 40.6 \\
\hline 50 & CEM II/A-V (50\% FA) & 3.0 & 4.1 & 5.7 & 11.3 & 23.3 & 29.2 \\
\hline
\end{tabular}




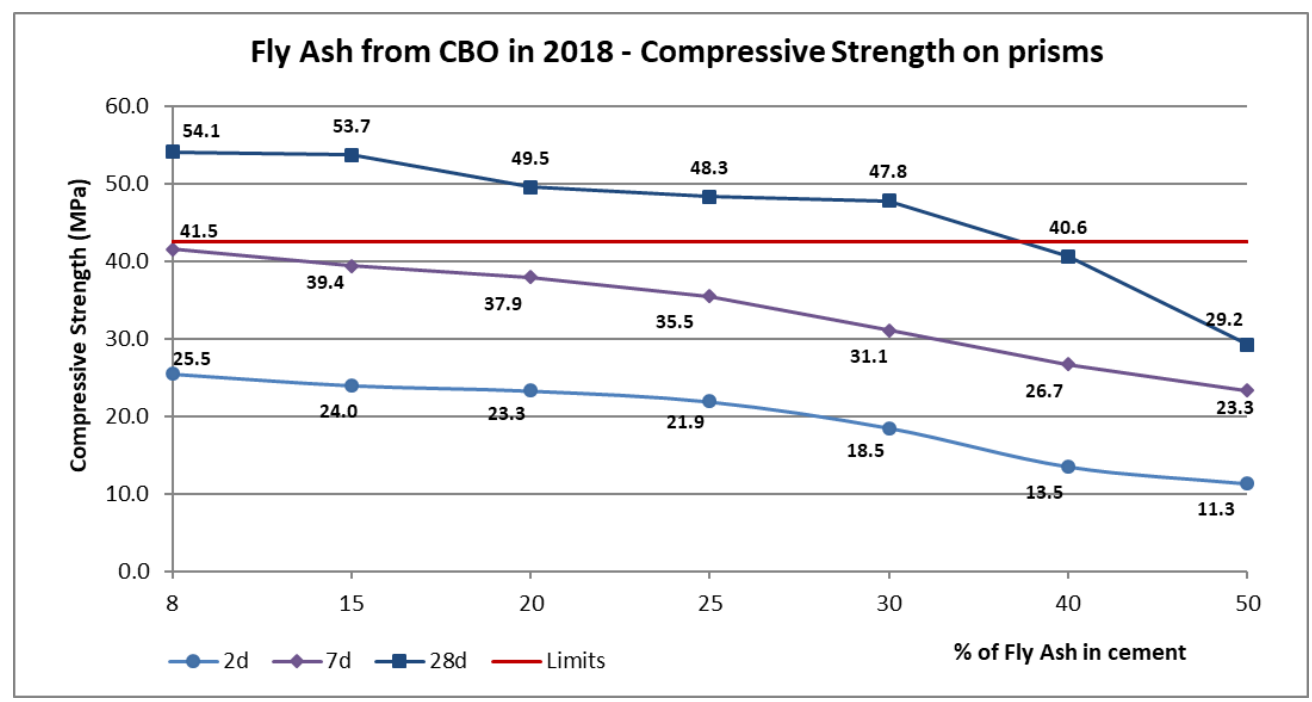

Fig. 9: Blend cement CEM II/A-V (CEM I 52.5 + \% Fly Ash after CBO with a LOI <2\%) in 2018.

From Fig 9 we can observe two distinct levels

- First level there is no significant difference between $8 \%$ to $15 \%$; compressive strength varies from $54.1 \mathrm{MPa}$ to $53.5 \mathrm{MPa}$

- Second level there is no significant difference between $20 \%$ to $30 \%$, compressive strength varies from 49.5MPa to $47.8 \mathrm{MPa}$

\section{4. Fly Ash from Thermax Carbon Burn Out (CBO)}

Tests performed on trial mixes in April 2019 with Fly Ash obtained from the Thermax Carbon Burn Out unit revealed the following results, which are further commented in the conclusion.

In the beginning of 2019, the process of CBO has been improved to obtain a Fly Ash with less carbon, compressive strength test has been carried out to compare with the initial Fly Ash used for testing at the start of the project in 2014 .

Table 2 showed comparison between:

- Control CEM I 52,5N without addition (LOI=2.16\%, Compressive strength on mortar 60.2 MPa@28d)

- Fly Ash as addition to CEM I 52.5

- Control CEM II/A 42.4-LL without addition (LOI=4.95\%\%, Compressive strength on mortar 44.8 MPa @ 28d)

- Fly Ash in CEM II/A-LL 42.5

To produce a CEM II/A 42.5 a maximum of $20 \%$ of Fly Ash is allowed as per BS EN 197-1, otherwise if Fly Ash addition is between $21 \%$ and $35 \%$ the Cement should be named as CEM II/B 42.5. That is why the trial mixes has been limited to an addition of Fly Ash of $20 \%$ maximum.

In mortar mix as per BS EN 197-1, the compressive strength for Control mix CEM I $52.5 \mathrm{~N}$ is $34 \%$ higher than the control mix CEM II/A 42.5. 
Table 2: FA with LOI $<2 \%$ as addition in CEM I 52.5 .

\begin{tabular}{|c|c|c|c|c|c|c|c|c|c|}
\hline \multirow[b]{2}{*}{ Mix C25/30 - April 2019} & \multicolumn{8}{|c|}{ Mix Design } & \multirow[b]{2}{*}{$\begin{array}{l}\text { Slump } \\
\text { (mm) }\end{array}$} \\
\hline & $\begin{array}{c}\text { Cement } \\
(\mathrm{Kg})\end{array}$ & $\begin{array}{c}\text { Fly Ash } \\
\text { (Kg) }\end{array}$ & $\begin{array}{c}\text { Rsand } \\
0 / 2 \mathrm{~mm} \\
(\mathrm{Kg})\end{array}$ & $\begin{array}{c}\text { Rsand } \\
0 / 4 \mathrm{~mm} \\
\text { (Kg) }\end{array}$ & $\begin{array}{c}\text { 4-10 mm } \\
(\mathrm{Kg})\end{array}$ & $\begin{array}{c}10-20 \mathrm{~mm} \\
(\mathrm{Kg})\end{array}$ & $w / C$ & $\begin{array}{c}\text { Plasticizer } \\
\text { RCS } 800\end{array}$ & \\
\hline Control CEM I 52.5N & 315 & 0.0 & 350 & 690 & 425 & 530 & 0.57 & $0.4 \%$ & 170 \\
\hline CEM I $52.5 \mathrm{~N}+10 \% \mathrm{FA}$ & 315 & 31.5 & 350 & 690 & 425 & 530 & 0.57 & $0.4 \%$ & 150 \\
\hline CEM I $52.5 \mathrm{~N}+15 \% \mathrm{FA}$ & 315 & 47.3 & 350 & 690 & 425 & 530 & 0.57 & $0.4 \%$ & 150 \\
\hline CEM I $52.5 \mathrm{~N}+18 \% \mathrm{FA}$ & 315 & 56.7 & 350 & 690 & 425 & 530 & 0.57 & $0.4 \%$ & 140 \\
\hline CEM I $52.5 \mathrm{~N}+20 \% \mathrm{FA}$ & 315 & 63.0 & 350 & 690 & 425 & 530 & 0.57 & $0.4 \%$ & 150 \\
\hline Control CEM II/A-LL 42.5N & 315 & 0.0 & 350 & 690 & 425 & 530 & 0.57 & $0.4 \%$ & 160 \\
\hline CEM II/A-LL $42.5 \mathrm{~N}+10 \%$ FA & 315 & 31.5 & 350 & 690 & 425 & 530 & 0.57 & $0.4 \%$ & 180 \\
\hline CEM II/A-LL $42.5 \mathrm{~N}+15 \%$ FA & 315 & 47.3 & 350 & 690 & 425 & 530 & 0.57 & $0.4 \%$ & 150 \\
\hline CEM II/A-LL 42.5N + 20\% FA & 315 & 63.0 & 350 & 690 & 425 & 530 & 0.57 & $0.4 \%$ & 180 \\
\hline
\end{tabular}

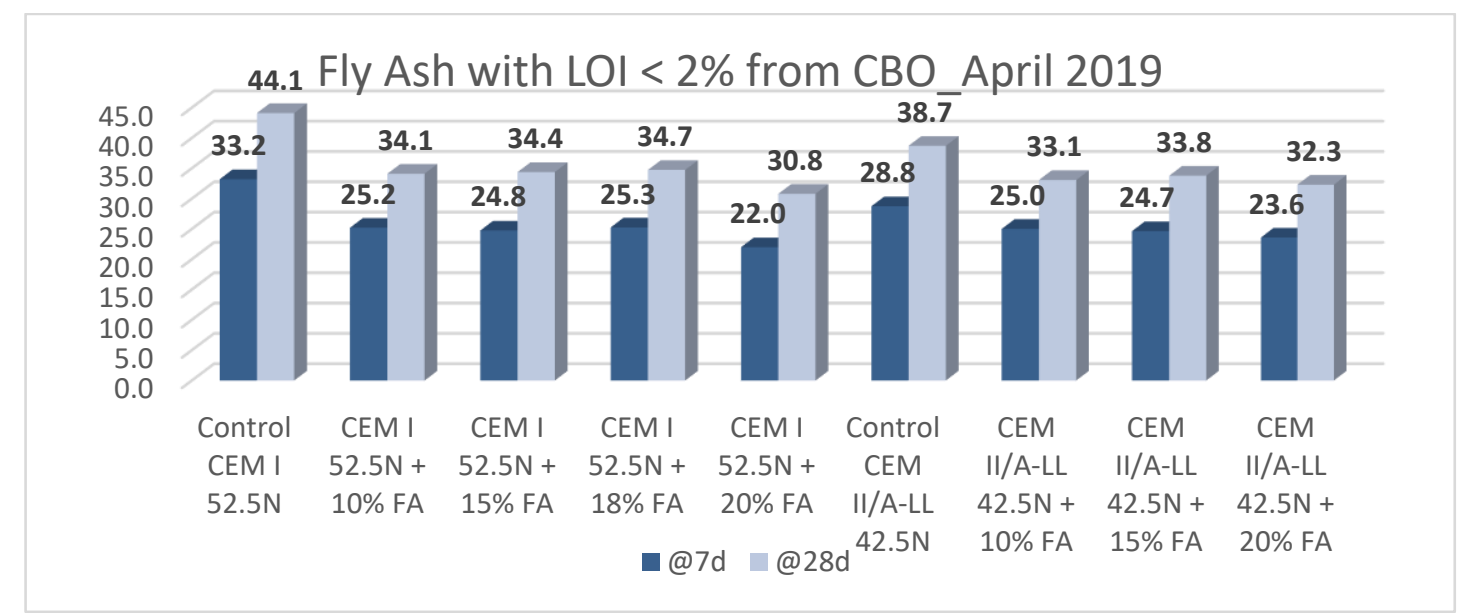

Fig. 10: CEM II/A-V (CEM I 52.5 + \% Fly Ash after CBO with a LOI <2\%) in 2019.

\section{Conclusion}

The study aimed to find percentage of Fly Ash which could be used as partial replacement in cement CEM I 42.5 and CEM I 52.5 to produce a new cement CEM II/A-V 42.5 which meet the requirements mentioned in BS EN 450-1

It is very important to note that in 2014 at the beginning of the study OTEO LB has sent Fly ash with a LOI $\geq 20 \%$ and Bottom Ash, LOI > 30\% to Pune in India. The Fly Ash and the Bottom Ash have been burnt in a pro-type CBO Thermax model producing a Fly Ash of LOI 4.99\%. 
1. From Fig 6, we can note that the compressive strength is broadly similar between $10 \%$ to $20 \%$ of Fly Ash and drastically decreases to $50 \%$ with $40 \%$ of Fly Ash.

2. However, the flexural strength (Fig7) remained constant up to 40\% of Fly Ash and starts to drop drastically when it reaches $50 \%$ of Fly Ash

3. A $15 \%$ of partial replacement (Fig 8) shows that the compressive strength is $10 \%$ lower than the control FA0 which can be explained by the strength activity index of $84 \%$ of the Fly Ash which is acceptable to a minimum of $85 \%$ as per BS EN 450-1

In 2018 OTEO LB has burnt the same type of Fly ash with a LOI $\geq 20 \%$ and Bottom Ash, LOI $>30 \%$ in the unique CBO in the world to produce a Fly Ash of LOI $<2 \%$

4. Concrete Control Mix CEM I $52.5 \mathrm{~N}$ is noted to be $12 \%$ higher than the control CEM II/A 42.5 whereas with $15 \%$ of Fly Ash in both CEM I 52.5 and CEM II/A 42.5, the concrete compressive strength is higher only by $1.7 \%$.

5. Similar to concrete (Fig 10) the maximum efficiency lies between 15\% - 20\% for mortars (Fig 9). However, the efficiency factor was higher for Fly Ash mortars than Fly Ash concrete samples up to nearly 25\%> Further increase in Fly Ash \% reduces efficiency factor for fly ash mortars compared to Fly Ash concrete, in terms of strength development.

6. Irrespective of Fly Ash \% and curing period, there is a good correlation between flexural strength and compressive strength.

7. Fly Ash between $10 \%$ - 20\% (Fig 10) shows broadly similar compressive strength, which can be explained by the strength activity index of $92 \%$ of Fly Ash obtained from the fly Ash of LOI $<2 \%$

National benefits: For decades, Mauritius has been an island that has been highly dependent on imported goods that makes it vulnerable to the world market price drops and inflations. This system classifies the country as being only a consumer, hence any unforeseen events in the world market that could cut off supply of these goods (cement and coal) would jeopardise its economy. Therefore, the need to switch from a linear economy (consumer) to a circular economy is vital due to the increasing demand of cement. In order to achieve this, one of the potential possibilities is to move towards a circular economy by using a cement with Fly Ash waste which also offers opportunities for businesses to expand and export whilst contributing to the decrease in carbon footprint, thus making Mauritius a Sustainable Island[17].

Technical benefits: Incorporating Fly Ash into the concrete mixture has the tendency to improve its workability and reducing the water requirements for a given consistency $[18,19,20]$. Concrete produced from cement containing fly ash has greater longevity as its ultimate strength is enhanced, as well as an improvement in both the permeability and durability of concrete to chemical attack is noted [21,22,23]. Furthermore, it can be used as a thermal cracking mitigator, as it lowers the heat of hydration and causes formation of ettringite to occur normally. Based on the test results with lower loss on ignition values, it can be concluded that substituting CEM I $52.5 \mathrm{~N}$ with a maximum of $20 \%$ Fly ash can be used to produce equivalent CEM II A-V 42.5 .

\section{References}

[1] M. Rafieizonooz, J. Mirza, M. R. Salim, M. W. Hussin, and E. Khankhaje, "Investigation of coal bottom ash and fly ash in concrete as replacement for sand and cement," Construction and Building Materials, vol. 116, pp. 15-24, 2016.

[2] M. D. A. Thomas, D. Hopkins, G. Girn, R. Munro, and E. Muhl, "The use of high-volume fly ash in concrete," in Proceedings of the 7th international gypsum and fly ash science and technology conference, Toronto, 2002.

[3] M. Abushad, and M. D. Sabri, "Comparative Study of Compressive Strength of Concrete with Fly Ash Replacement by Cement," International Research Journal of Engineering and Technology (IRJET), vol. 4, no. 7, pp. 2627- 2630, 2017. 
[4] W. S. Langley, and G. H. Leaman, "Practical uses for high-volume fly ash concrete utilizing a low calcium fly ash," Special Publication, vol. 178, pp. 545-574, 1998.

[5] V. H. Nguyen, N. Leklou, J. E. Aubert, and P. Mounanga, "The effect of natural pozzolan on delayed ettringite formation of the heat-cured mortars," Construction and Building Materials, vol. 48, pp. 479-484, 2013.

[6] A. Pavoine, X. Brunetaud, and L. Divet, "The impact of cement parameters on Delayed Ettringite Formation," Cement and Concrete Composites, vol. 34, no. 4, pp. 521-528, 2012

[7] L. Coppola, R. Troli, P. Zaffaroni, G. Belz, and Collepardi, "Influence of unburnt carbon in the performance of concrete mixtures," vol. 178, 1998.

[8] Mauritius CEB annual reports publication, 2017.

[9] Mauritius Central Statistics Office (CSO), 2018.

[10] The Technical Advisory Committee report (TAC), Report of Republic of Mauritius, 2008.

[11] D. I. Barnes, and L. K. A. Sear, "Ash utilisation from Coal-based power plants," Quality Ash Association, 2006.

[12] K. Styszko-Grochowiak, J. Gołaś, H. Jankowski, and S. Koziński, "Characterization of the coal fly ash for the purpose of improvement of industrial on-line measurement of unburned carbon content," Fuel, vol. 83, no. 13, pp. 1847-1853, 2004

[13] N. Bouzoubaâ, M. H. Zhang, A. Bilodeau, and V. M. Malhotra, "P. K. Mechanical Properties and Durabilitiy of Concrete with High Volume Fly Ash Blended Cement," Sixth CANMET/ACI/JCI International Conference, vol. 575, 1998.

[14] M. Collepardi, S. Collepardi, J. O. Olagot, and F. Simonelli, "The influence of slag and fly ash on the carbonation of concrete," in Proc. of 8th CANMET/ACI Int. Conf. on Fly Ash, Silica Fume, Slag, and Natural Pozzolans in Concrete, 2004, pp. 23-29.

[15] Chindaprasirt and al., "Influence of Mae Moe Fly Ash Fineness on Characteristics Strength and Drying Shrinkage Development of Blended Cement Mortars," Eighth East Asia-Pacific conference on Structural Engineering and Construction, Singapore, no. 1191, 2001, pp. 6.

[16] S. Tangtermsirikul, "Development of Fly Ash usage in Thailand," Proceedings of the International Workshop on Project management, Kochi, Japan: pg 39-49, 2005.

[17] V. M. Malhota, and K. P. Mehta, Pozzolanic and cementitious materials, 2004.

[18] V. M. Malhotra, and P. K. Metha, High-Performance High-Volume Fly Ash Concrete: Materials, Mixture Proportioning, Properties, Construction practice, and Case Histories. Second edition. January 2005.

[19] Y. Phethany, P. Julnipitawong, W. Saengsoy, S. Tangtermsisrikul, "study on workability and compressive strength of high LOI Fly Ash," $7^{\text {th }}$ International conference of Asian Concrete Federation -Hanoi Vietnam, 2016.

[20] R. Somna, C. Jaturapitakkul, and A. M. Amde, "Effect of ground fly ash and ground bagasse ash on the durability of recycled aggregate concrete," Cement and concrete composites, vol. 34, no. 7, pp. 848-854, 2012.

[21] M. Thomas, K. Folliard, T. Drimalas, and T. Ramlochan, "Diagnosing delayed ettringite formation in concrete structures," Cement and concrete research, vol. 38, no. 6, pp. 841-847, 2008.

[22] M. D. A. Thomas, D. Hopkins, G. Girn, R. Munro, and E. Muhl, "The use of high-volume fly ash in concrete," in Proceedings, 7th international gypsum and fly ash science and technology conference, Toronto., 2002

[23] M. H. Zhang, M. C. Blanchette, and V. M. Malhotra, "Leachability of trace metal elements from fly ash concrete: results from column-leaching and batch-leaching tests," Materials Journal, vol. 98, no. 2, pp. 126-136, 2001. 